\title{
Erratum to: A review of guidelines for use of growth hormone in pediatric and transition patients
}

\author{
David M. Cook $\cdot$ Susan R. Rose
}

Published online: 2 March 2012

(C) Springer Science+Business Media, LLC 2012

\section{Erratum to: Pituitary}

DOI 10.1007/s11102-011-0372-6

In Current recommendations for GH therapy among transition patients section of the published article, the text "total and low-density lipoprotein levels in adults" should be read as: However, replacement therapy for GHD has been shown to increase lipolysis and cardiovascular function and to decrease low-density lipoprotein levels in adults.

The online version of the original article can be found under doi:10.1007/s11102-011-0372-6.

D. M. Cook $(\bowtie)$

Department of Endocrinology, Diabetes, and Clinical Nutrition, Oregon Health and Science University, 3181 South West Sam Jackson Park Road, Suite 140, Portland, OR 97239, USA

e-mail: cookd@ohsu.edu

\section{S. R. Rose}

Department of Endocrinology, Cincinnati Children's Hospital Medical Center, University of Cincinnati, 3333 Burnet Avenue, Cincinnati, OH 45229, USA 